\title{
PENGARUH KREATIVITAS GURU DALAM MEMBENTUK KEPERIBADIAN PESERTA DIDIK DI MTs AL ANSHORI QOMARUL HUDA DESA WAJEGESENG
}

\author{
Abdul Hafiz Alfatoni \\ UIN Sunan Kalijaga Yogyakarta \\ hafizalaftoni70@gmail.com
}

\begin{abstract}
This study aims to determine whether there is an effect of teacher creativity in shaping the personality of students at MTs Al anshory Qomarul Huda, Wajageseng Village, 2020/2021 academic year. Due to the low personality of students in their daily behavior because of the rampant promiscuity. This is shown when the learning process takes place some students do not pay attention, most students do not do the exercises in the book if they are not ordered by the teacher. Students do not have a good personality to behave in accordance with existing norms. There are even students who do not do assignments even though they have been ordered by the teacher. This research was conducted at Madrasab MTs Al anshory Qomarul Huda, Wajageseng Village with quantitative research type ex post facto design. The population in this study were all students of class VIII totaling 25 people and a sample of 25 people was drawn using saturated samples to test the instrument. Data collection techniques in this study used were documentation, tests and questionnaires. By looking at the average value in the questionnaire is 7.70 and the test has an average value of 7.28. By looking at the coefficient table of the teacher creativity variable $=0.772$ so that it is known that the amount of the contribution of teacher creativity to personality is $77.2 \%$, so that it can be concluded by looking at the results of the calculation on the $t$ test, namely the $t$ count on the teacher creativity variable with a significant level of $5 \%$ of 0.005 The significance of learning independence is 0.004 and it is obtained that tcount $=3.326$ and ttable, $0.05 ; 24=1.176$ indicates that 3.326> 1.176. The results showed that there was a positive influence of teacher creativity on the personality of students at MTs Al Anshory Qomarul Huda Desa Wajageseng in the academic year 2020/2021.
\end{abstract}

Keywords: Teacher Creativity, Personality, Students

\begin{abstract}
Abstrak : Penelitian itu betujuan agar kita mengetahui apakah terdapat Pengaruh kreativitas guru dalam membentuk kepribadian peserta didik di MTs Al anshory Qomarul Huda Desa Wajageseng tahun pelajaran 2020/2021. Dikarenakan rendahnya kepribadian peserta didik dalam berprilaku sehari-hari karena maraknya pergaulan bebas. Hal ini ditunjukkan pada saat proses belajar berlangsung sebagian siswa tidak memperhatikan, sebagian besar siswa tidak mengerjakan latihan soal yang ada dibuku kalau tidak diperintah guru. Siswa belum mempunyai kepribadian yang baik untuk berprilaku sesuai dengan norma yang ada. Bahkan ada siswa yang tidak mengerjakan tugas meskipun sudah diperintah guru. Penelitian ini dilakukan di Madrasah MTs Al anshory Qomarul Huda Desa wajageseng dengan jenis penelitian kuantitatif desain expost facto. Populasi pada penelitian ini adalah seluruh peserta didik kelas VIII berjumlah 25 orang dan ditarik sampel berjumlah 25 orang dengan
\end{abstract}


menggunakan sampel jenuh untuk diuji coba instrumen. Teknik pengumpulan data dalam penelitian ini digunakan adalah dokumentasi, tes dan angket. Dengan melihat nilai rata-rata pada angket sebesar 7,70 dan tes memiliki nilai rata-rata sebesar 7,28. Dengan melihat pada tabel koefesien variabel kreativitas Guru $=0,772$ sehingga diketahui jumlah sumbangan kreativitas guru terhadap kepribadian sebesar 77,2\%, sehingga dapat ditarik kesimpulan dengan melihat hasil perhitungan pada uji t yaitu diperolehnya thitung pada variabel kreativitas guru dengan taraf signifikan $5 \%$ sebesar $0,005>$ signifikansi pada kemandirian belajar yaitu 0,004 dan diperoleh $\mathrm{T}_{\text {hitung }}=3,326$ dan $\mathrm{T}_{\text {tabel, }, 05 ; 24}=1,176$ menunjukkan bahwa 3,326 > 1,176. Hasil penelitian menunjukkan bahwa terdapat pengaruh positif kereativitas guru terhadap kepribadian peserta didik di MTs Al Anshory Qomarul Huda Desa wajageseng tahun pelajaran 2020/2021.

Kata kunci: Kreativitas Guru, Kepribadian, Peserta Didik

\section{PENDAHULUAN}

Pada abad yang ke dua puluh satu ini banyak sekali orang mulai berpikiran bahwa Pendidikan ialah sebuah jalan yang mampu menjadikan tingkah laku anak didik menjadi lebih baik. Peribal demikian di sebabkan pembelajaran diharapkan mempunyai kedudukan berarti untuk kehidupan serta masa depan manusia. Pembelajaran dapat membentuk manusia yang bisa membedakan mana perbuatan yang benar serta mengathui perbuatan yang tidak benar. Spesialnya digolongan pelajar, pembelajaran jadi kunci masa depan mereka. Lewat pembelajaran, siswa diharpakan bisa aktif serta giat supaya bisa membina induvidu yang unggul dan bertngkah laku baik. Pembelajaran ialah suatu jalan untuk menolong peserta didik meningkatkan segala kemampuan yang meraka punya. Kemampuan yang selalu dilatih merupakan kemampuan dalam hal kebikan supaya peserta didik dapat merih kesusksesan yang mereka dambakan. Kemampuan peserta didik yang tidak baik dengan adanya pembelajaran yang meraka tempu diharpan mampu mengahalangi agar hal dmikian tidak menjadi kebiasan dalam sehari-hari. ${ }^{1}$

Pembelajaran dapat kita artikan menjadi sebuah pola serta metode dalam mengembangkan kehidupan manusia dalam berbagai aspek kehidupan yang iahadapi, nyaris nibil terdapat kelompok manusia yang tidak memakai pembelajaran selaku pembudayaan serta kenaikan kualitasnya, sekalipun dalam kelompok warga masyarakat. ${ }^{2}$ Tidak hanya itu, pembelajaran sampai saat ini merupaka cara yang paling baik dalam menciptakan pribadi yang baik terhadap peserta didik.. Oleh sebab itu, pembelajaran secara selalu dibentuk serta dibesarkan supaya

\footnotetext{
${ }^{1}$ Helmawati, Pendidikan karakter sehari-hari (Bandung: PT Remaja Rosdakarya, 2017), 1.

2 Muzayyin Arifin, Kapita selekta pendidikan Islam, Edisi Revisi (Jakarta: Bumi Aksara, 2016),
} 69. 
menciptakan generasi yang diharapkan. Demikian pula dengan pembelajaran di negara tercinta ini. Bangsa Indonesia tidak mau jadi bangsa yang bodoh serta terbelakang, paling utama dalam mengalami era yang terus tumbuh diera kecanggihan teknologi serta komunikasi. Hingga, revisi sumber energi manusia yang pintar, terampil, mandiri serta berakblak mulia terus diupayakan lewat proses Pembelajaran. ${ }^{3}$

Globalisasi ini hendak menimbulkan terbentuknya Akulturasi asimetris (Asymmetrical acculturation). Akulturasi asimetris mendesake terdapatnya penetrasi budaya asing kewilayah budaya yang nasional sesuatu bangsa yang menyebabkan terbentuknya transformasi budaya yang timpang. Dengan terdapatnya globalisasi pula, warga bisa mengakses hal- hal yang tidak cocok dengan syari" at agama serta jati diri bangsa Indonesia. Budaya- budaya asing yang berlawanan dengan syari" at Agama serta budaya bangsa banyak yang diadopsi oleh warga. Apalagi, saat ini tidak sedikit warga yang mulai menjadikan budaya asing tersebut jadi style bidup, dengan terdapatnya peribal tersebut sangat bertolak balik dengan kepribadian bangsa Indonesia, yang sangat menjunjung besar nilai, tata kerama, adat, serta budaya yang terdapat dalam masyarakatnya. Moralitas bangsa ini seolah telah rusak serta tergadai kan ditengah arus deras kemajuan ilmu pengetahuan serta teknologi. ${ }^{4}$

Salah satu upayanya merupakan lewat pembelajaran kepribadian. Upaya ini, tidak hanya jadi bagian dari proses pembuatan akblak anak bangsa, pula diharapkan sanggup jadi fondasi utama dalam menyukseskan Indonesia pada waktu mendatang. Pembelajaran kepribadian sebetulnya telah tercermin dalam Undang- Undang No 20 Tahun 2003 tentang Sistem Pembelajaran Nasional, yang berbunyi:

"Pendidikan nasional berfungsi mengembangkan kemampuan dan membentuk watak serta peradaban bangsa yang bermartabat dalam rangka mencerdaskan kehidupan bangsa, bertujuan untuk berkembangnya potensi peserta didik agar menjadi manusia yang beriman dan bertakwa kepada Tuhan Yang Maha Esa, berakhlak mulia, sehat, berilmu, cakap, kreatif, mandiri dan menjadi warga negara yang demokratis serta bertanggung jawab".

Dalam Undang- Undang Sistem Pembelajaran Nasional tersebut, kepribadian berarti yang semestinya dibentuk merupakan supaya anak didik menjadi manusia yang beriman, serta

${ }^{3}$ Akhmad Muhaimin Azzet e Meita Sandra, Urgensi pendidikan karakter di Indonesia: revitalisasi pendidikan karakter terbadap keberhasilan belajar dan kemajuan bangsa (Yogyakarta: Ar-Ruzz Media, 2011), 5.

${ }^{4}$ Syahraini Tambak, «Pendidikan Komunikasi Islam», Jakarta: Kalam Mulia, 2013, 89. 
bertakwa kepada Tuhan Yang Maha Esa. Sangat, inilab perihal berarti yang semestinya memperoleh atensi dalam pembelajaran kita. Dengan demikian, pemahaman beriman serta bertakwa kepada Tuban itu hendak jadi kekuatan yang dapat melawan apabila anak didik terbawa- bawa perbuatan yang tidak terpuji. Terlebih, peribal ini terus menjadi dikuatkan dengan pengembangan kepribadian yang berikutnya ialah berakblak mulia. ${ }^{5}$

Pada dasarnya pembelajaran moral ataupun akhlak sangatlah berarti guna menunjang terdapatnya pembelajaran kepribadian. Pembelajaran moral sangat berarti ditanamkan buat siswa secepat bisa jadi, selaku perlengkapan buat membentengi pengaruh- pengaruh bertabiat negatif dari luar ataupun dalam sekolah yang memiliki dampak kurang baik untuk akhlak serta sikap siswa. Siswa yang melaksanakan aksi tepuji dan berakhlakul karimah ialah hasil dari pengalaman serta pengetahuan mereka dari pelajaran yang diberikan oleh kedua orang tua, para guru di sekolah ataupun area dekat. Pola pembelajaran dini sangat dibutuhkan untuk pertumbuhan psikis siswa, mulai dari pembelajaran awal ialah pembelajaran keluarga ataupun pembelajaran resmi serta non resmi. Tidak bisa disangkal, kalau pola pembelajaran moral agama semenjak dini ialah salah satu kunci buat membentengi Iman serta akhlak bagi para pelajar. $^{6}$

Bersumber pada perihal yang dikemukakan di atas hingga bisa dilihat kalau salah satu kepribadian yang wajib tercipta dalam sikap partisipan didik merupakan kenaikan keimanan serta ketaqwaan kepada Tuhan yang maba esa. Iman serta taqwa kepada Tuban sesungguhnya ialah landasan yang kokoh buat terjadinya kepribadian yang yang lain yang meliputi kepribadian terhadap diri sendiri, sesama, area, serta kebangsaan yang tercipta lewat olah pikir, olah hati, olah raga, serta olah rasa dan karsa. Sehingga tercipta kepribadian manusia( insan kamil) yang utuh semacam yang disebutkean pada tujuan pembelajaran kepribadian yang sudah disebutkan di atas.

Pengamalan dan penerapan pembelajaran kepribadian yang butub ditanamkan pada partisipan didik, wajib diintegrasikan terhadap mata pelajaran yang terdapat pada sesuatu lembaga pembelajaran dan diintegrasikan lewat budaya sekolah. Dengan terdapatnya pengintegrasian tersebut, hingga bendak nampak gimana kedudukan seseorang guru dalam mengaplikasikan kepribadian apa saja yang bisa diterapkan oleh sesuatu lembaga pembelajaran. Sama halnya dengan moral serta etika bisa dipupuk dengan aktivitas religius, aktivitas yang

\footnotetext{
${ }^{5}$ Azzet e Sandra, 12.

${ }^{6}$ Toto Tasmara, Membudayakan etos kerja islami (Gema Insani, 2002), 66.
} 
diajarkan selaku pembiasaan kepada partisipan didik di sekolah bisa berbentuk: berdo' a serta bersyukur, melakukan aktivitas di Mushola, memperingati hari raya keagamaan cocok dengan agamanya, mengadakan aktivitas keagamaan cocok dengan agamanya.

Nilai religious( Keberagamaan) bersumber dari agama serta sanggup merasuk ke alam intimitas jiwa. Penanaman nilai religius ini berarti dalam rangka buat menguatkan etos kerja serta etos ilmiah segala civitas akademika yang terdapat dalam lembaga pembelajaran tersebut. Perilaku serta sikap religius ialah perilaku serta sikap yang dekat dengan halhal spiritual. Seorang diucap religius keala dia merasa butub serta berupaya mendekatkan dirinya dengan Tuhan ( selaku penciptanya), serta patuh terhadap ajaran agama yang dianutnya. Perilaku dari religius tersebut, umumnya nampak serta dipelajari lewat mata pelajaran Pembelajaran Agama Islam. $^{7}$

\section{KAJIAN PUSTAKA}

\section{Pengertian Kreativitas}

M. Ali didalam bukunya ia mengutip pendapat Baron bahwa kreativitas merupakan keahlian dalam membuat hal yang baru. Hal demikian bukan berarti membuat sesuatu yang baru akan tetapi dapat juga mengembangkan hal yang telah ada sebelumnya. ${ }^{8}$ Sebagai seorang guru dalam hal ini berkewajiban untuk mengembangkan serta memajukan Pendidikan yang ada. Hal demikian seorang guru dituntut mempunyai kreativitas dalam memajukan Pendidikan agar ia dapat dikatakan seorang guru yang unggul. Berbicara tentang kreativitas yang harus dimiliki oleh seorang guru ada tiga cakupan yang perlu diperhatkan. Pertama seorang guru diharapkan mampu memahami serta mempunyai solusi ketika adanya masalah. Kedua seorang guru diharpakan mampu merancang startegi yang ada dalam segala dalam konteks Pendidikan. Ketiga seorang guru diharpkan mampu menciptakan hal-hal baru.

\footnotetext{
7 Novan Ardy Wiyani, «Manajemen pendidikan karakter: konsep dan implementasinya di sekolah», 2012, 13.

${ }^{8}$ Mohammad Ali, Psikologi Remaja: Perkembangan Peserta Didik. (Jakarta: Bumi Aksara, 2006), 41.
} 


\section{Ciri- ciri Kreativitas Guru}

Dalam menumbubkan kemampuan yang dimiliki oleh peserta didik, diharpakan seorang guru mempunyai kreativitas yang bisa mendukung serta mengembangkan kemampuan yang dimiliki anak. Berbicara tntang ciri-ciri guru yang kreativ diantaranya. Pertama guru harus mempunyai gagasan yang luas serta tidak mudah menyerah dengan rintangan yang ada. Kedua guru diharapakn memberikan penghargaan terhadap peserta didik yangmampu berkarya. Ketiga guru harus mampu sebagai penyemangat bagi peserta didik. Keempat seorang guru dibarapkan menilai perilaku mapun karya peserta didik dalam berbgai aspek. Kelima guru dalam hal ini memberian peluang bagi peserta didik agar mampu memngebangkan yang ia miliki.."

\section{Factor- Factor Yang Mempengaruh Kreativitas Guru}

Berbicara mengenai penyebab laju pertumbuban manusia pada dasarnya merupakan hasil dari kombinasi antara gen yang ia miliki dan dipengarubi oleb lingkungan yang mereka tempati. Pada kenyataannya dalam lingukunganya, mereka mampu mengembangkan diri dari proses sebelumnya, yang dilandasi dengan polo fikir yang baik dalam menyelsaikan berbagai macam problematika yang ia daptatkan. Dalam hal ini seorang guru diharapkan selalu mengembangkan pola pikirnya agar dapat dengan mudah menyelesikan permasalahan yang ada. Menurut para abli kreativitas ialah kombinasi dari kecerdasan yang dimiliki, mental yang baiak serta mempunyai gairah yang kuat dalam kepribadian yang ia miliki. Hal demikian yang membuat adanya kerativitas pada diri seseorang. ${ }^{10}$

Kecerdasan seseorang dapat kita uraikan yaitu megatahui berbgaia hal, berikir jernih, dapat merumuskan kesalahan, kreativitas yang baik, mepunyai keterampilan dalam menentuan suatu kebiakan dengan adil dan dapat memadukan kemampuannya dalam berbagai hal. Kemampuan dalam menciptakan sesuatu yang kreatif, dapat diartikan bahwa kemampuan yang dimiliki sesorang merupakan sesuatu yang dimiliki secara sistematis. Adapun ciri-ciri orang yang mempunyai kepribadian serta memiliki prisnsif dalam hidup diantranya kaingin untuk berprstasi yang tinggi, giat dalam bekerja,

9 Yusuf Syamsu e A. Juntika Nurihsan, «Landasan Bimbingan \& Konseling», Bandung: Remaja Rosdakarya, 2005, 247.

10 S.C. Utami Munandar, Kreativitas dan keberbakatan: strategi mewujudkan potensi kreatif dan bakat (Jakarta: Gramedia Pustaka Utama, 1999), 2. 
peka terhadap keadaan yang ada serta berani mengambil keputusan dengan baik.

Lingkungan sesorang dapat mempengarubi kemampuan yang dimiliki, pengarub yang datang dari factor lingkungan diharpakan seorang guru mampu untuk mengembangkan potensi yang ia miliki. Dalam hal ini factor dari luar dapat kita bagi menjadi empat bagian diantranya. Pertama bagaimana Pendidikan yang dimiliki oleh guru. Kedua mempunyai pengalaman dalam mengajar. Tiga selalu mengikuti pelatihan tentang keguruan. Kemapat adanya organisasi yang menaungi guru agar guru bias sejabtera. Hal demikian banyak. kita temukan yang melatar belakangi seorag guru mempunyai propesi ganda untuk memenubi kebuthan yang ada, karna sebgaimana kita ketahui sampai saat ini banyak guru yang blom menadpatkan kesejatraan. Sehinga waktu mengjar tidak efektif karna adanya kegandaan dalam berpropesi sehingga maksimal dalam mengajar kita tidak dapatkan. Hal ini dapat mempengarubi kurangnya kreativitas dalam mengajar seorang guru karna terpokus dalam propesi yang lain untuk memenubi kebutuban biupnya ${ }^{11}$

\section{Pengertian Pembentukan Keperibadian Peserta Didik}

Keperibadian peserta didik dalam hal ini ada beberpa factor yang mengarubuimnya diantaranya. Pertama kemapuan yang ia miliki. Kedua dapat membedakan mana yang baik dan mana yang salah. Ketiga tidak mementikan ego yang dimiliki. Adapun teori yang mebahas tentang kepribadian diantaranya teori kognif, teori behavior, teori humanitic dan teori psikoanalisa. Ada pun factor yang tidak mencerminkan keperibadian sseorang ialah potensi ketidak samaan antara satu sama lain. ${ }^{12}$

Adapun didalam psikologi yang bercorak islam nampaknya kewenangan dan kemampuan potensi manusia untuk mewujudkan citra kepribadiannya harus diakui tidak hanya ditentukan oleh yang bersangkutan dengan berbagai dinamika unsur kepribadian yang dimiliki, akan tetapi ketentuan Alloh sangat dominan dalam menentukan citra kepribadian seseorang. Beberapa teori yang merupakan pijakan untuk. mengetahui lebih rinci tentang kepribadian diangtranya. Pertama Teori Empirisme yaitu

${ }^{11}$ Nurdin Hamzah \& Mohamad, «Belajar dengan Pendekatan PAIKEM», Jakarta: Bumi Aksara, 2011, 156.

12 Hamim Rosyidi, PSIKOLOGI KEPRIBADIAN: PARADIGMA PSIKOANALISA, Psikologi Perkembangan (Paradigma Psikoanalisa) (Surabaya: Jaudar Press, 2012), 21, http://digilib.uinsby.ac.id/6252/. 
teori yang beranggapan babwa kepribadian di dasarkan pada lingkungan pendidikan yang di dapatnya atau perkembangan jiwa seseorang semata-mata bergantung kepada pendidikan dengan segala aktivitasnya, pendidikan merupakan salah satu lingkungan anak didik. Kedua Teori Nativisme dalam bal iniTeori ini menitik beratkan babwa kepribadian terbentuk oleh sifat bawaan, keturunan dan kebakaan sebagai penentu timbulnya tingkah laku seseorang. Aliran ini di pelopori oleh Arthur Houer. Ketiga Teori Konvergensi yaitu Teori yang menggabungkan dua aliran di atas. Konvergensi adalah interaksi faktor intern dan faktor lingkungan dalam factor pembentukan kepribadian, penentuan kepribadian seseorang ditentukan kerja yang integral antara faktor yang internal (potensi bawaan) maupun faktor eksternal (lingkungan pendidikan). Islam juga mengakui bahwa kepribadian dapat di pengarubi oleh faktor dasar dan faktor ajar. Sebagaimana ada dalam hadist yang maksudnya adalah manusia labir mempunyai potensi bawaan dan kemudian dapat pula dipengarubi oleh faktor luar, dalam hal ini adalah orang tuanya. ${ }^{13}$

\section{Proses Pembentukan Keperibadian}

Berbicara tentang pembentukan kepribadian dalam bal ini guru dalam implementasinya dapat menggunaan beberapacara dalam menanmkan keperibadian tehadapat peserta didik diantaranya. Pertama guru harus sebagai contob tehadap peserta didik artinya guru tidak hanya terfukus dengan teori yang ada akan tetapi guru diharpakan mampu mengajak peserta didik untuk menerapkan apa yang meraka ketahui. Kedua membiasakan murid untuk selalu mengerjakan hal yang bias membentuk. kemapuannya. Ketiga menerpakan kdisplinan agar peserta didik membiasakan diri untuk menunda-nunda pekerjaan yang menjadi kewajibannya dengan menerpkan aturanaturan yang bias membuat peserta didik. jera ketike berbuat kesalahan.. ${ }^{14}$

\section{METODE PENELITIAN}

Dalam penelitian ini metode yang digunakan ialah penelitian kuantitatif. Penelitian kuantitatif merupakan penelitian yang bisa dikatan penelitian yang dilandasi oleh filsafat Positivisme, yang dimana hal demikian dipergunakan dalam meneliti

13 Djunaidatul Munawwarah, Filsafat Pendidikan Perspektif Islam dan Umum (Jakarta: UIN Press, 2003), 57-60.

${ }^{14}$ Suralaga Fadhilah, Psikologi Pendidikan Dalam Persepektif Islam (Jakarta: UIN Press, 2005), 89-91. 
popuasi maupun sempelyang ada, dalam pengumpulan sumber data dengan memakai istrumen penelitian, menggunakan statistic dalam menganalisis data, dengan harapan mampu menguji hipotesis yang ia kemukakan. ${ }^{15}$

\section{HASIL DAN PEMBAHASAN}

\section{Uji Normalitas}

Uji normalitas data dilakukan untuk mengetahui apakah data berdistribusi normal atau tidak. Dalam penelitian ini uji normalitas data menggunakan rumus chi-kuadrat $\left(\mathrm{x}^{2}\right)$ diperoleh harga statistik uji untuk tingkat signifikansi 5\% pada hasil angket kreativitas guru dan tes hasil kepribadian pada VIII MTs Al Anshory Qomarul Huda Desa Wajageseng disajikan dibawah ini.

\section{Hasil uji normalitas angket dan tes}

\begin{tabular}{|c|c|c|}
\hline HASIL & $\mathrm{X}_{\text {tabel }}^{2}$ & $\mathrm{X}_{\text {hitung }}^{2}$ \\
\hline Angket & 11,0705 & 5,59684 \\
\hline Tes & 11,0705 & 6,14273 \\
\hline
\end{tabular}

Berdasarkan tabel 4.3 telah diperoleh hasil dari Angket kreativitas guru pada taraf signifikan $5 \%$ dengan $\mathrm{dk}=6-1=5$ diperoleh $\mathrm{x}_{\text {tabel }}^{2}=$

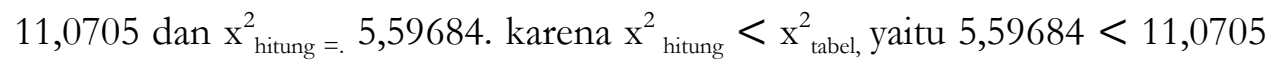
maka data angket tersebut berdistribusi normal. Dan hasil dari tes kepribadian pada taraf signifikansi 5\% dengan $\mathrm{dk}=6-1=5$ diperoleh $\mathrm{x}_{\text {tabel }}^{2}$ $=11,0705$ dan $x_{\text {hitung }}^{2}$ 6,14273 karena $x^{2}{ }_{\text {hitung }}<\mathrm{x}_{\text {tabel, }}^{2}$ yaitu 6,14273<11,0705 maka data tes tersebut berdistribusi normal.

\section{Uji Homogenitas}

Uji homogenitas data dilakukan untuk mnguji data penelitian yang sudah diperoleh apakah homogen atau tidak. Dari data hasil angket diperoleh varians $=2,5281$ sedangkan dari data hasil tes diperoleh varians $=4,5796$ maka dapat diperoleh $\mathrm{F}_{\text {hitung }}$ :

\footnotetext{
${ }^{15}$ Sugiyono, 8.
} 


$$
\begin{aligned}
\mathrm{F} & =\frac{\text { Varian terbesar }}{\text { Varian terkecil }} \\
\mathrm{F} & =\frac{4,5796}{2,5281} \\
& =1,811
\end{aligned}
$$

Berdasarkan hasil uji homogenitas data, diperoleh nilai $\mathrm{F}_{\text {hitung }}=3,28$ dan $\mathrm{F}_{\text {tabel }}=4,26$ pada taraf signifikan 5\%(0,05) ternyata $\mathrm{F}_{\text {hitung }}<\mathrm{F}_{\text {tabel }}$ yaitu $1,811<4,26$ sehingga dapat disimpulkan bahwa data tersebut bersifat homogen.

\section{Hasil Pengujian Hipotesis}

Setelah semua analisis uji prasyarat data dihitung, maka dapat dilakukan analisis hipotesis. Sebelum melakukan uji hipotesis, terlebih dahulu hipotesis alternatif ( $\mathrm{Ha}$ ) yang ada pada bab III diubah menjadi hipotesis nihil (Ho) yaitu hipotesis kerja yang mengatakan "Diduga ada pengaruh kemandirian belajar terhadap penguasaan konsep pada tema 4 kelas V'. Dalam penelitian ini uji hipotesis peneliti menggunakan uji hipotesis persial (uji t) sebagaiamana yang tertera dalam bab III penelitian ini. Penelitian ini dengan melihat pengaruh antara variabel bebas terhadap variabel terikat dengan taraf signifikan 0,05 . Berdasarkan rumus hipotesis hasil nilai hitung $t_{\text {hitung }}$ dan $t_{\text {tabel }}$ :

- Jika nilai $\mathrm{t}_{\text {hitung }}>\mathrm{t}_{\text {tabel }}$ maka variabel bebas ( $\mathrm{x}$ ) berpengaruh terhadap variabel terikat $(\mathrm{y})$.

- Jika nilai $\mathrm{t}_{\text {hitung }}<\mathrm{t}_{\text {tabel }}$ maka variabel bebas ( $\mathrm{x}$ ) tidak berpengaruh trhadap variabel terikat (y).

Berdasarkan nilai signifikansi dari hasil output SPSS:

- Jika nilai sig. >0,05 maka variabel bebas (x) berpengaruh signifikan terhadap variabel terikat(y).

- Jika nilai sig. <0,05 maka variabel bebas (x) tidak berpengaruh signifikan terhadap variabel terikat (y).

- Dari pengujian yang dilakukan menggunakan SPSS 20 diperoleh data sebagai berikut: 


\section{Hasil analisis hipotesis}

\section{Coefficients $^{\mathrm{a}}$}

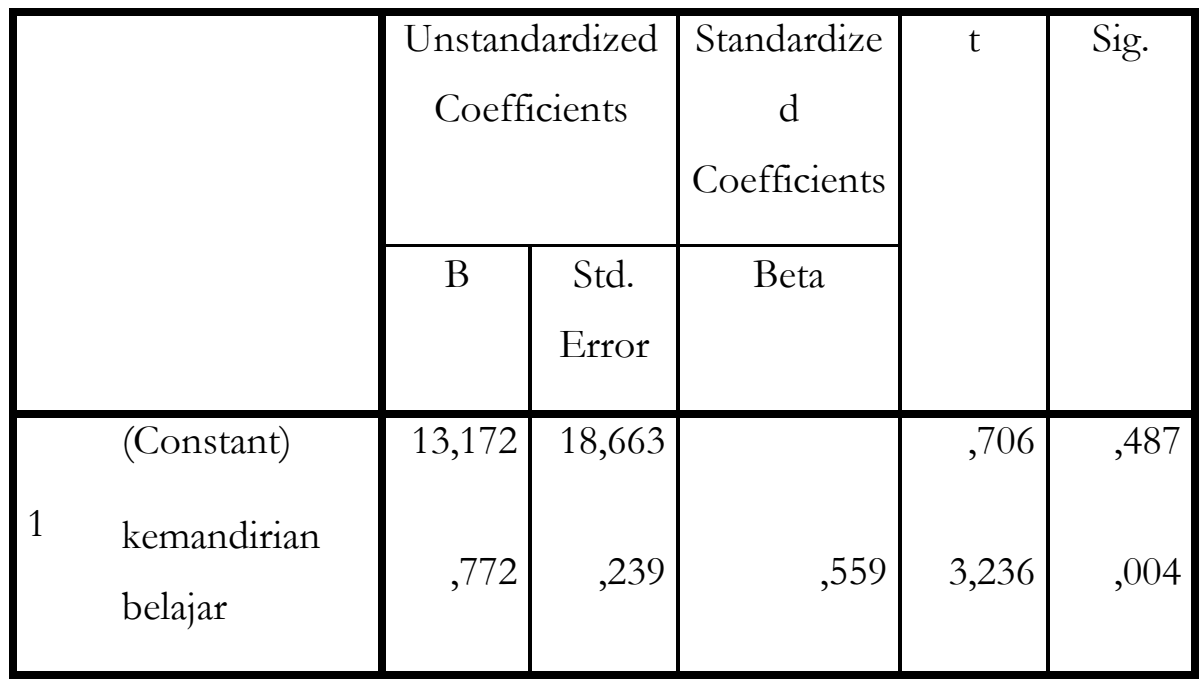

a. Dependent Variable: kepribadian

Berdasarkan hasil output SPSS 20 diatas dapat dilihat pada taraf signifikan 5\% diperoleh $\mathrm{df}=\mathrm{k}-1$ atau $25-1=24$ diperoleh $\mathrm{t}_{\text {tabel }}=1,711$ dan $t_{\text {hitung }}=3,236$ karena $t_{\text {tabel }}<t_{\text {hitung }}$ yaitu 1,711 $<3,236$. dengan tingkat signifikan dibawah 0,05 yaitu 0,004, berdasarkan uji persial dalam analisis regresi dapat disimpulkan bahwa Ho di tolak dan $\mathrm{Ha}$ diterima sehingga dinyatakan bahwa kreativitas guru sangat berpengaruh terhadap kepribadian pada VIII MTs Al Anshory Qomarul Huda Desa Wajageseng.

\section{Pembahasan Hasil Penelitian}

Berdasarkan hasil penelitian diperoleh nilai tertinggi dari hasil angket Kepribadian peserta didik 90 dan nilai terendahnya 60, skor tertinggi dari hasil tes penguasaan konsep 90 dan nilai terendah 50. Berdasarkan perhitungan berbantuan Ms. Excel yang telah dilakukan terhadap data yang diperoleh maka nilai rata-rata (mean) angket 77,80 dan tes 73,28 . Melihat dari 
rata-rata yang diperoleh pada hasil analisis data angket dan tes maka nilai siswa dapat dikelompokkan dalam kategori sebagai berikut:

Tabel

Klasifikasi kriteria angket kreativitas guru

\begin{tabular}{|c|c|}
\hline Kriteria & Kategori \\
\hline $86-100$ & Sangat baik \\
\hline $66-85$ & Baik \\
\hline $46-65$ & Cukup \\
\hline $26-45$ & Kurang \\
\hline $0-25$ & Sangat kurang \\
\hline
\end{tabular}

Sumber: Fifi Anggraini.2013

Berdasarkan rata-rata yang diperoleh dari hasil kreativitas guru yaitu 77,80 secara umum dapat digolongkan baik. Sehingga dapat dikatakan bahwa tingkat Kepribadian peserta didik kelas VIII MTs Tsanawiyah Al-Anshory Qamarul Huda Wajageseng adalah baik. Untuk lebih jelasnya dapat dilihat pada lampiran distribusi hasil angket kemandirian belajar peserta didik.

Tabel

Klasifikasi kriteria hasil tes kepribadian

\begin{tabular}{|c|c|}
\hline Kriteria & Kategori \\
\hline $81-100$ & Tinggi \\
\hline $51-80$ & Sedang \\
\hline $31-50$ & Rendah \\
\hline $0-30$ & Sangat rendah \\
\hline
\end{tabular}

Sumber: Fifi Anggraini.2013

Berdasarkan rata-rata yang diperoleh dari hasil tes penguasaan konsep yaitu 73,28 termasuk dalam kategori tinggi. Sehingga dapat dikatakan bahwa baiknya kreativitas guru akan meningkatkan kepribadian peserta didik menjadi lebih baik lagi. 
Tingginya hasil rata-rata pada angket dari pada tes menunjukkan bahwa tingginya kepribadian pada peserta didik. Dilihat dalam variabel kepribadian dengan indikator yaitu memiliki perencanaan dalam belajar yaitu memiliki Akhlak yang baik, memiliki inisiatif dalam belajar, memiliki rasa tanggung jawab terhadap tugas yang diberi dan memiliki motivasi tinggi dalam persaingan dalam proses belajar. Dalam variabel Kepribadian, siswa cenderung merespon baik dalam menjawab pernyataan yang diberikan, hal ini dapat dilihat dari hasil kuisioner angket dengan skor rata-rata dari masingmasing indikator pernyataan dalam kategori tinggi, maka dapat disimpulkan tingginya pendapat yang diberikan responden dalam menjawab kuesioner pada pernyataan indikator kepribadian menunjukkan bahwa peserta didik kelas VIII MTs Tsanawiyah Al-Anshory Qamarul Huda Wajageseng dapat dikatakan telah memiliki Kepribadian yang baik.

Dengan adanya kepribadian yang baik pada peserta didik tentunya akan memudahkan peserta didik dalam berperilaku sehari- hari. Karena kepribadian yang baik pada peserta didik tentunya akan berpengaruh pada kepribadian yang kurang menjadi meningkat, tingkat kepribadian tidak baik akan sedikit demi sedikit membaik, dan kepribadian yang tidak baik tidak akan terjadi lagi. Sehingga dikatakan bahwa pengaruh kreativitas guru dalam membentuk kepribadian peserta didik sangat dipengaruhi kepribadian pada peserta didik tersebut.

Adapun hasil analisis data yang didapat dari pengolahan data normalitas dan homogenitas yang berbantuan hitung Ms. Excel 2007, diketahui data berdistribusi normal dan homogen. Uji normalitas pada angket dan tes di peroleh $\mathrm{T}_{\text {hitung }}=6,1423<\mathrm{T}_{\text {tabel }}=11,0705$ dan untuk angket diperoleh $\mathrm{T}_{\text {hitung }}=$ $5,59684<\mathrm{T}_{\text {tabel }}=11,0705$ menunjukkan kedua data berdistribusi normal. penelitian mengenai pengaruh kreativitas guru terhadap hasil tes kepribadian menunjukkan bahwa kreativitas guru berpengaruh signifikan positif terhadap hasil tes kepribadian. Hal ini ditunjukkan melalui hasil pada tabel koefesien, diperoleh nilai pada konstan $=13,172$ dan koefesien variabel kreativitas guru (x) diperoleh nilai $=0,772$, maka diketahui bahwa apabila meningkat setiap 
satu angka pada kreativitas guru maka semakin tinggi tingkat kepribadian pada pesefta didik. Dan diperoleh nilai t-hitung pada variabel kreativitas guru dengan taraf signifikan sebesar 0,004 kurang dari 5\%, dan diperoleh $\mathrm{T}_{\text {hitung }}=$ 3,326 dan $\mathrm{T}_{\text {tabel, }, 05 ; 24}=1,176$ menunjukkan bahwa 3,326 $>1,176$ maka $\mathrm{Ha}$ diterima dan Ho ditolak artinya bahwa pengaruh kreativitas guru dalam membentuk kepribadian peserta didik berpengaruh terhadap kepribadian peseta didik MTs Tsanawiyah Al-Anshory Qamarul Huda Wajageseng tahun pelajaran 2020/2021.

\section{KESIMPULAN}

Berdasarkan hasil penelitian dan pembahasan, melihat pengaruh kreativitas guru dalam membentuk kepribadian peserta diperoleh dari data hasil penyebaran angket untuk mengukur seberapa jauh kreativitas guru memiliki nilai rata-rata sebesar 7,70 dan tes kepribadian memiliki nilai rata-rata sebesar 7,28. Hal ini didapat dari hasil penyebaran angket dan tes terhadap 25 responden yang dimana terdapat 15 orang peserta didik dengan kategori sangat baik, 5 orang peserta didik dalam kategori baik dan 5 orang peserta didik dalam kategori cukup maka dapat ditarik kesimpulan dengan melihat hasil perhitungan regresi linear pada uji $t$ yaitu diperolehnya $t_{\text {hitung }}$ pada variabel kreativitas guru dengan taraf signifikan 5\% sebesar 0,005 > signifikansi pada kreativitas guru yaitu 0,004 dan diperoleh $T_{\text {hitung }}=3,326$ dan $T_{\text {tabel, }, 05 ; 24}=1,176$ menunjukkan bahwa 3,326 > 1,176 maka Ha diterima dan Ho ditolak artinya bahwa pengaruh kreativitas guru berpengaruh dalam membentuk kepribadian peserta didik di MTs Al Anshory Qomarul Huda Desa wajageseng tahun pelajaran 2020/2021.

\section{DAFTAR PUSTAKA}

Arifin, Muzayyin. Kapita selekta pendidikan Islam. Edisi Revisi. Jakarta: Bumi Aksara, 2016.

Azzet, Akhmad Muhaimin, e Meita Sandra. Urgensi pendidikan karakter di Indonesia: revitalisasi pendidikan karakter terbadap keberhasilan belajar dan kemajuan bangsa. Yogyakarta: Ar-Ruzz Media, 2011.

Fadhilah, Suralaga. Psikologi Pendidikan Dalam Persepektif Islam. Jakarta: UIN Press, 2005. 
Hamzah \& Mohamad, Nurdin. «Belajar dengan Pendekatan PAIKEM». Jakarta: Bumi Aksara, 2011.

Helmawati. Pendidikan karakter sehari-hari. Bandung: PT Remaja Rosdakarya, 2017.

Mohammad Ali. Psikologi Remaja: Perkembangan Peserta Didik. Jakarta: Bumi Aksara, 2006.

Munandar, S.C. Utami. Kreativitas dan keberbakatan: strategi mewnjudkan potensi kreatif dan bakat. Jakarta: Gramedia Pustaka Utama, 1999.

Munawwarah, Djunaidatul. Filsafat Pendidikan Perspektif Islam dan Umum. Jakarta: UIN Press, 2003.

Nazir, Moh. «Metode Penelitian Cetakan Keenam». Jakarta: Penerbit Ghalia Indonesia, 2005.

Rosyidi, Hamim. PSIKOLOGI KEPRIBADLAN : PARADIGMA PSIKOANALISA. Psikologi Perkembangan (Paradigma Psikoanalisa). Surabaya: Jaudar Press, 2012. http://digilib.uinsby.ac.id/6252/.

Sugiyono, Dr. Metode penelitian kuantitatif dan R\&D. Bandung: Alfabeta, 2010.

Syamsu, Yusuf, e A. Juntika Nurihsan. «Landasan Bimbingan \& Konseling». Bandung: Remaja Rosdakarya, 2005.

Syamsuddin, M. Din, e Abd Rohim Ghazali. Etika agama dalam membangun masyarakat madani. Cet. 1. Jakarta: Logos Wacana Ilmu, 2000.

Tambak, Syahraini. «Pendidikan Komunikasi Islam». Jakarta: Kalam Mulia, 2013.

Tasmara, Toto. Membudayakan etos kerja islami. Gema Insani, 2002.

Wiyani, Novan Ardy. «Manajemen pendidikan karakter: konsep dan implementasinya di sekolah», 2012. 